\title{
Vastuullisuutta vastalääkkeeksi johtamisallergiaan
}

Collin, Kaija \& Lemmetty, Soila (toim.) Siedätystä johtamisallergiaan! Vastuullinen johtajuus itseohjautuvuuden ja luovuuden tukena työelämässä. Helsinki, Edita, 2019, 339 sivua.

Kirjoitan tätä arviota kevään kynnyksellä, jolloin on oiva aika miettiä allergioille siedättymistä. Johtamisallergia voi ilmetä työyhteisöissä esimerkiksi näkyvän johtamisen ja hierarkioiden häivyttämisenä sekä vastuun siirtämisenä työntekijöille, joiden odotetaan olevan itseohjautuvia ja saamansa vapauden ansiosta luovia, motivoituneita ja hyvinvoivia. Toisaalta "esimiehettömiksi" pyrkivät organisaatiot voivat unohtaa henkilöstönsä tuuliajolle, jolloin vapaus muuttuukin laiminlyömiseksi, luovuus kyynisyydeksi ja hyvinvointi kuormittumiseksi tuen ja rakenteiden puuttuessa. Molemmat näkökulmat ovat nykymaailmassa ajankohtaisempia kuin koskaan. Kokonaiset työyhteisöt joutuivat koronaviruksen aiheuttamien poikkeustoimien ajamina yhtäkkiä etätöihin. Itseohjautuvuus tarkoitti monelle omien työtehtävien kanssa luovimista pakotetun digiloikan, etäkoululaisten ohjaamisen, kauppakassitilausten ja vessapaperimeemien ristipölytyksessä. Mitä Collinin ja Lemmetyn toimittama kirja voi tarjota uuden vuosikymmenen poikkeuksellisen alun kokeneille työntekijöille?

Teoksen taustalla on Työsuojelurahaston rahoittama HeRMo-hanke, jonka tavoitteena oli tutkia eettistä henkilöstöjohtamista luovan toiminnan tukena kasvuyrityksissä. Hankkeesta syntyi vahvasti tutkimuspohjaiseen tietoon perustuva teos, jonka kirjoitta- miseen osallistui 22 työelämän asiantuntijaa. Edustettuina ovat niin yliopistotutkijat kuin teknologia- ja it-alojen sekä muotoilun luovat ammattilaiset. Kirja on jaettu kolmeen osaan. Ensimmäisenä lukija johdatetaan sisälle ilmiöön teorian ja käsitteiden kautta. Ehkä tämä voidaan nähdä eräänlaisena prick-testinä: ensin on tiedettävä, millaisista allergeeneistä puhutaan, ennen kuin niitä voidaan ryhtyä hoitamaan. Toinen osa sukeltaa syvemmälle HeRMo-hankeessa kerättyihin tutkimushavaintoihin. Nämä löydökset pohjautuvat hankkeessa kerättyihin havainnointi-, haastatteluja kyselylomakeaineistoihin. Ne voidaan nähdä pyrkimyksinä löytää siedätysmuotoja allergian pahimpiin oireisiin. Kirjan kolmas ja viimeinen osa - joka on selvästi muita suppeampi - tarjoaa siedätyshoidon osalta käytännön esimerkkejä, "ääniä työelämästä", organisaatioiden jäsenten itsensä kertomana.

Ensimmäinen osa tarjoaa monipuolisen katsauksen ilmiöihin, jotka kirjoittajat ovat nähneet keskeisinä johtamisallergian ymmärtämisessä. Luvuissa paneudutaan ajattelun muutokseen parempien johtamiskäytänteiden reunaehtona sekä vastuulliseen johtamiseen ja sen ilmenemiseen organisaatioissa. Lisäksi käydään läpi itseohjautuvuuden, autonomian ja luovuuden käsitteet. Lopuksi tutustutaan valmentavaan esimiestyöhön yhtenä esimerkkinä vastuullisesta tavasta tukea luovuutta ja itseohjautuvuutta työssä. Kirjoittajat nostavat näitä keskeisiä nykytyöelämän ilmiöitä esille paradoksien kautta, puhumalla esimerkiksi ristiriidasta tasapuolisen kohtelun ja työntekijälähtöisyyden välillä. Tällaisen vastakkain- 
asettelun vaihtoehtona näen tärkeäksi myös perinteisen "vitamiiniajattelun", jonka keskiössä on oikean tasapainon löytäminen haitallisten ääripäiden väliltä. Voimme siis todeta, että on ongelmallista tasapuolistaa kaikki työntekijät pakottamisen kautta, esimerkiksi tarjoamalla kaikille täsmälleen saman verran samanlaista tukea työhön. Toisaalta on yhtä lailla haitallista sallia kaikille itseohjautuvuuden nimissä täysin vapaat yksilölliset mahdollisuudet ilman mitään ohjaavia raameja, jolloin jokainen saa esimerkiksi itse valita, millaista tukea ja miten paljon sitä saa.

Kirjan toinen osa koostuu hankkeen löydöksiä esittelevistä luvuista, ja se muodostuu paikoin hieman puuduttavaksi tulosluetteloksi. Aineistoista on poimittu keskeisiin ilmiöihin liittyviä havaintoja, mutta ne jäävät usein vain lukuisien alakäsitteiden listaamiseksi lyhyiden aineistoesimerkkien kautta. Esimerkkinä vaikkapa luovuus ja sen ilmeneminen kasvuyrityksissä, johon liittyen lukijalle esitellään kolme pääkäsitettä: luova toimijuus, luova toiminta ja luovat lopputulemat. Tämän jälkeen kutakin näitä käsitellään tarkemmin suhteessa aineistoista tunnistettuihin alakäsitteisiin, joita on tunnistettu yhteensä 12 kappaletta. Lukija pohtiikin ajoittain, voiko kirjasta saada tartunnan käsiteallergiasta.

Toisaalta kirjan parasta antia ovat napakat tiivistelmät, jotka tavoittavat oivallisesti nykytyöelämän haasteita ja mikä parasta, uskaltavat ottaa niihin myös suoraan kantaa. Tästä esimerkkinä vaikkapa toteamus siitä, että "on selvää, että ihmislähtöinen organisaatiokulttuuri on (...) ainoa järkevä lähtökohta paremmalle liiketoiminnalle".

Kuvaamani vitamiinimalli paradoksien vaihtoehtona nousee esille kirjan viimeisessä osassa, jossa kuullaan konkreettisia esimerkkejä työelämän käytänteistä. Erilaisista työyhteisöistä lukiessaan saa ymmärrystä siitä, miten pienessä, kasvunsa alkutaipaleella olevassa yrityksessä vastuun tasainen jakautuminen ilman esimiehiä voi toimia helpostikin, kun henkilöstöä on alle 30 ja kaikki ovat toistensa kavereita. Haasteita syntyy, kun kasvun myötä kysymykset vastuun kantamisesta ja esimerkiksi oikeudenmukaisista palkitsemiskäytänteistä lisääntyvät: vapaa toimintakulttuuri alkaa kaivata ympärilleen jonkinlaisia rakenteita, jotka selkiyttävät toimintaa.

Kokonaisuutena teoksen erityiset ansiot löytyvät sen tutkimusperusteisuudesta. Kirja välttää helpot "konsulttiniksit", joilla voidaan kyllä houkutella lukijakuntaa ja saada organisaatioiden menestys ja kehittyminen näyttämään helpolta pikku projektilta. Todellisuudessa muutos harvoin onnistuu yhtä ja samaa reseptiä näppärästi noudattamalla tai yhtä allergialääkettä ottamalla. Sen sijaan kirja esittelee tutkimustietoon nojaten niin luovuuden, itseohjautuvuuden kuin vastuullisuudenkin moninaisina ilmiöinä, jotka ovat voimakkaasti konteksti- ja tilannesidonnaisia. Toisaalta tällainen realistinen kuvaus todellisuudesta, kuten kirjassa osuvasti mainitaan, "sotku eri ihmisten intressejä, haluja, himoja ja tavoitteita, jotka eivät joka tilanteessa voi olla yhteneviä", ei välttämättä innosta HR-ammattilaisia tai muita organisaation kehittäjiä paneutumaan syvällisesti aiheeseen ja pohtimaan juuri omaan työyhteisöön sopivia vastuullisia, työntekijälähtöisiä ja valmentavia käytänteitä itseohjautuvuuden tukemiseksi.

Ehkä raflaavaksikin ajateltu teoksen nimi jää hieman irralliseksi, sillä lukija ei juurikaan löydä vastaavaa tyyliä kirjan sisällöstä. Ajoittain olisi ollut virkistävää lukea enemmänkin rohkeita avauksia tieteellisen, objektiivisen ja paikoin varovaisen tekstityylin rinnalla. Tätä ajoittain raskasta asiatyyliä olisi voinut keventää vaikkapa jatkamalla allergiaanalogiaa pidemmälle: millaisia siedätystoimia meidän kannattaisi johtamisallergiaa vastaan lähteä toteuttamaan? Tulisiko meidän pyrkiä altistamaan organisaatioita pienissä määrin, ja jos, niin mille? Kuten kirjan lopussa todetaan, on helppoa sanoa, että paras tulos saavutetaan vastuullisesti tuotetuilla käytänteillä, joissa on huomioitu ihmislähtöisyys. Tosin käytännössä pysähtyminen juuri oman 
kontekstin ja työn tilanteiden äärelle, sekä niihin yksilöllisesti sovellettujen mallien kehittäminen, testaaminen ja implementointi voidaan kokea liian aikaa vieväksi ja monimutkaiseksi.

Nykyisellään kirja soveltuu parhaiten oppimateriaaliksi. Työnsä ohessa siihen tutustuva johtaja tai HR-asiantuntija saattaa jättää tämän melko massiivisen paketin kesken itseohjautuvan työnsä haasteiden lomassa. Toisaalta, jos kirja tavoittaa esimerkiksi johtamista tai työelämän ja organisaatioiden psykologiaa opiskelevia henkilöitä, se voi toivottavasti toimia sysäyksenä ajattelun muutokseen. Ja tämä, kuten kirjan ensimmäisessä luvussa todetaan, on keskeistä johtajuuden ja työelämän muuttamiseksi. Ehkä johtamisallergian paras siedätyskonsti onkin kyseisessä luvussa mainittu peili, eli muutoksen aloittaminen omasta itsestä. Se vaatii kykyä kyseenalaistaa ja arvioi- da myös omia uskomuksiaan kriittisesti sekä pysähtyä pohtimaan, miten itse voin muuttua.

Entä mitä kirja sitten tarjosi korona-ajan epätyypilliselle työelämälle? Ainakin tärkeän muistutuksen siitä, että itseohjautuvuus ei ole taito, joka meidän tulisi automaattisesti osata. Se ei ole ominaisuus, joka siirtyy itsestään selvästi tilanteesta toiseen. Kuten kirjoittajat toteavat, uusissa tilanteissa me kaikki tarvitsemme tukea ja apua. Erityisesti näinä haastavina aikoina tarvitsemme hyviä käytänteitä sekä johtamista, joka kohdistuu oikeisiin asioihin ja kannattelee kohti valoisampia päiviä.

\section{Kirjoittaja}

Mari Huhtala, PsT, dos., yliopistotutkija, Jyväskylän yliopisto, sähköposti: mari.huhtala@jyu.fi 